\title{
KONSEPTUALISASI OMNIBUS LAW DALAM MENYELESAIKAN PERMASALAHAN REGULASI PERTANAHAN
}

\author{
Firman Freaddy Busroh \\ Sekolah Tinggi Ilmu Hukum Sumpah Pemuda (STIHPADA) Palembang \\ Jl. Kol. H. Animan Achyad Kota Palembang \\ Email: firmanbusroh@stihpada.ac.id
}

\begin{abstract}
One of the factorsthat hampers theimprovement of the investment climatein Indonesia is due to regulatory issues. Regulatory issues related to several industries including the land sector. Based on data from the Ministry of Agricultural and Spatial Planning/National Land Agency of Republic of Indonesia there are about 632 regulations related to land whereas 208 are no longer valid leaving only 424 regulations applicable. Regulation of some 424 hadimplementationproblems and conflicts between agencies.The primary key of law enforcement begins with the quality of theregulation. Due to regulation which has many shortcomings that need to be addressed to improve the investment climate in Indonesia. To overcpme these problems the Minister of Agrarian and Spatial Planning / National Land Agency of the Republic of Indonesia, Mr. Sofyan Jalil threw the idea of omnibus law to resolve regulations problems that influence the growth of investment in Indonesia. Sofyan jalil said that the government is discussing the legislation remedial solutions through the Omnibus Law. Omnibus Law's existence has been known in legal theories from common law countries. However, the existence of omnibus law is still lessknownamong the academic community of the faculty of law in Indonesia. For that purpose than this article to understand the omnibus law and its use to resolve the regulatory issues in Indonesia.
\end{abstract}

Key words: omnibus law, legislation, harmonization, regulatory reform

\begin{abstract}
Abstrak
Salah satu faktor yang menghambat peningkatan iklim investasi di Indonesia disebabkan karena permasalahan regulasi. Permasalahan regulasi terkait dengan beberapa bidang industri diantaranya adalah bidang pertanahan. Berdasarkan data yang dirilis dari Kementerian Agraria dan Tata Ruang/Badan Pertanahan Nasional Republik Indonesia ada sekitar 632 regulasi yang terkait bidang pertanahan dimana 208 peraturan sudah tidak berlaku lagi sehingga yang berlaku 424 regulasi. Regulasi sebanyak 424 beberapa memiliki permasalahan penerapannya dan benturan antar instansi. Padahal kunci utama penegak hukum dimulai dari kualitas mutu regulasi yang berlaku. Akibat regulasi yang memiliki banyak kekurangan maka perlu untuk dibenahi karena menjadi faktor penghambat peningkatan iklim investasi di Indonesia. Untuk mengatasi permasalahan tersebut maka Menteri Agraria dan Tata Ruang/Kepala Badan Pertanahan Nasional Republik Indonesia Bapak Sofyan Jalil melontarkan gagasan konsep Omnibus Lawuntuk menyelesaikan pemasalahan regulasi yang menghambat pertumbuhan investasi di Indonesia. Sofyan jalil mengatakan bahwa pemerintah tengah menggodok solusi perbaikan undang-undang melalui Omnibus Law. Keberadaan Omnibus Law sudah dikenal dalam teori-teori hukum. Teori Omnibus Law berasal dari negara yang menganut sistem hukum common law. Akan tetapi keberadaan Omnibus Lawmasih kurang diketahui dikalangan civitas akademika fakultas hukum di Indonesia. Untuk itu tujuan daripada tulisan ini untuk memahami Omnibus Lawdan penggunaannya untuk membenahi permasalahan regulasi di Indonesia.
\end{abstract}

Kata kunci: omnibus law, peraturan perundang-undangan, harmonisasi, reformasi regulasi 


\section{Latar Belakang}

Salah satu faktor penyebab terjadinya konflik pertanahan di Indonesia antara lain disebabkan adanya permasalahan regulasi dibidang pertanahan. Beberapa peraturan perundang-undangan yang terkait bidang pertanahan sering kali berbenturan satu sama lain. Sebagaimana dikemukakan oleh Ruslan Burhani yang dikutip dari laman Antaranews. com Kepala BPN RI Hendarman Supandji yang sebelumnya pernah mengemukakan permasalahan regulasi di bidang pertanahan dan BPN akan bekerja sama dengan lembaga perguruan tinggi, para praktisi dan lembagalembaga terkait baik dari pemerintah maupun lembaga swadaya masyarakat (LSM) untuk dapat memberikan masukan guna harmonisasi dan sinkronisasi terhadap peraturan di bidang agraria yang berjumlah 632 peraturan. Setelah dilakukan penelaahan hampir sebanyak 208 peraturan sudah tidak berlaku lagi, sehingga jumlah peraturan pertanahan yang masih berlaku di Indonesia sekitar 424 peraturan. Peraturan perundang-undangan dimaksud terdiri dari berbagai tingkatan tata urutan peraturan perundang-undangan dari tingkat Undang-undang sampai dengan surat edaran yang dikeluarkan oleh kementerian ${ }^{1}$.

Akibat permasalahan regulasi tersebut mengakibatkan pejabat pengambil kebijakan yang tidak memahami struktur peraturan perundang-undangan terkait dapat berujung kepada kesalahan administratif, kerugian keperdataan maupun perbuatan pidana.Hal ini mengakibatkan pejabat pengambil kebijakan menjadi ragu bahkan takut untuk mengambil kebijakan karena dapat berdampak hukum baginya.

Kebijakan hukum pertanahan di Indonesia sudah lama diatur dalam berbagai peraturan perundang-undangan yang berasal dari Belanda berdasarkan asas konkordansi. Produk hukum dari Negara Belanda tersebut antara lain Agrarische Wet, Agrariche Besluit, Burgerlijk Wetboek, Koninklijk Besluit, Regering Reglement, Indische Staatsregeling. Peraturan-peraturan tersebut sangat merugikan bangsa Indonesia dan menguntungkan bangsa penjajah.

Salah satu hak atas tanah yang diatur pada masa penjajahan Belanda antara lain hak eigendom yaitu hak milik yang mutlak pada umumnya diberikan kepada kaum penjajah serta diberikan kepastian hukum dengan didaftarkan kedalam register buku tanah. Sedangkan masyarakat pribumi asli Indonesia tidak memiliki bukti kepemilikan hak tanah karena masih menganut paham hukum adat sehingga apabila ada bukti kepemilikan adat berupa girik, ketitir, pipir dan sejenisnya. Alas hak tersebut masih sering dipergunakan pada saat proses pendaftaran tanah.

Setelah kemerdekaan Indonesia, pemerintah pada saat itu menyusun peraturan perundang-undangan mengenai agraria melalui Panitia Agraria yang dibentuk pada

1 Ruslan Burhani, “BPN Sederhanakan Aturan Pertanahan”, http://www.antaranews.com/berita/376127/bpnsederhanakan-aturan-pertanahan, diakses 12 April 2017. 
saat itu sehingga lahirlah Undang-undang Nomor 5 Tahun 1960 tentang Peraturan Dasar Pokok-Pokok Agraria yang selanjutnya disebut UUPA yang diberlakukan sejak tanggal 24 September 1960 sampai dengan sekarang.

Keberadaan UUPA memiliki asas-asas yang penting antara lain asas sosial, asas penguasaan negara, asas kepastian hukum. Adapun yang menjadi Grundnorm UUPA tersebut berpijak pada Pasal 33 ayat (3) UUD NRI Tahun1945.

Indonesia telah melewati rezim pemerintahan dari pemerintahan Orde Lama hingga Orde Reformasi. Pergantian Presiden dankabinet pemerintahan yang mengakibatkan lahirnya banyak peraturan perundangundangan sesuai keinginan masing-masing pemerintahan yang berkuasa saat itu. Hal ini kemudian menimbulkan persoalan regulasi dimana ada beberapa peraturan perundangundangan yang tumpah tindih sehingga menimbulkan konflik kebijakan antara satu kementerian/departemen dengan kementerian/ departemen lainnya. Hal tersebut menjadi perhatian pemerintah dan para praktisi di bidang agraria. Untuk menyelesaikan persoalan regulasi tersebut dibutuhkan suatu terobosan hukum yang tepat dan salah satu jalan keluarnya melalui konsep Omnibus Law.

Bagi sebagian kalangan masyarakat masih terasa asing mendengar istilah Omnibus Law. Bahkan beberapa kalangan akademisi hukum masih memperdebatkan konsep Omnibus Law tersebut bila diterapkan dikhawatirkan akan mengganggu sistem ketatanegaraan Indonesia karena disinyalir penyebabnya sistem hukum yang dianut di Indonesia yang dominan adalah Civil Law, sedangkan Omnibus Law ini berasal dari sistem hukum Common Law. Inilah kemudian gagasan tersebut menjadi menarik untuk dikaji dari sistem hukum yang berlaku di Indonesia.

Dari uraian tersebut timbul permasalahan yang akan dibahas yaitu apakah gagasan Omnibus Law dapat menyelesaikan permasalahan regulasi bidang pertanahan di Indonesia?

\section{Pembahasan}

Indonesia merupakan negara hukum sebagaimana dinyatakan dalam Konstitusi Indonesia yang dinyatakan dalam Pasal 1 ayat (3) UUD NRI Tahun 1945 yaitu Negara Indonesia adalah negara hukum (Rechtstaats) bukan negara kekuasaan (Machtsstaat). Pada negara yang menjunjung tinggi hukum memiliki tujuan hukum antara lain ketertiban, ketentraman, kedamaian, kesejahteraan dan kebahagiaan dalam tata kehidupan bermasyarakat ${ }^{2}$.

Negara yang menjunjung tinggi hukum harus berlandaskan hukum yang ajeg, kuat dan memberikan rasa keadilan.Hukum memang dibuat oleh negara tidak sematamata menjadi alat perekayasa sosial, tetapi lebih dari itu untuk menegakkan keadilan dan melindungi harkat manusia. Tidak sedikit

2 Firman Freaddy Busroh, Teknik Perundang-undangan suatu Pengantar, (Jakarta: Cintya Press, 2016), hlm. 17. 
hak-hak kemanusiaan yang dipercayakan kepada hukum untuk dijaga atau dilindungi, sebab tanpa adanya perlindungan hukum, akan banyak terjadi perbuatan pelanggaran hukum.

Pada dasarnya hukum merupakan normanorma yang sifatnya memaksa dan mengikat dimana mengatur tingkah laku manusia yang dibentuk oleh lembaga yang berwenang. Keberadaan hukum harus dipatuhi oleh manusia dan bila dilanggar maka akan diberikan hukuman berupa sanksi sebagaimana telah disepakati oleh masyarakat.

Salah satu pendapat hukum dari Soerjono Soekanto memberikan banyak pengertian hukum sebagai berikut, antara lain hukum sebagai tata hukum yaitu terdiri dari struktur dan proses perangkat kaidah-kaidah hukum yang berlaku pada suatu waktu dan tempat tertentu serta berbentuk tertulis ${ }^{3}$. Hukum dimaknai sebagai tata hukum memiliki posisi yang sangat penting sebagai dasar bertindak pemerintah.

Jika suatu negara sudah memposisikan dirinya sebagai negara hukum (rechtsstaat), maka konsekuensinya produk peraturan perundang-undanganlah yang menjadi tolak ukur rule of the game di tengah kehidupan masyarakat, dimana kandungan norma di dalamnya akan menyebut soal larangan, perintah, kepatuhan, dan sanksi yang mengikat.
Hukum berisi norma perlindungan kepentingan rakyat seperti keadilan, kebebasan menentukan pilihan, perlakuan yang adil, perlakuan yang manusiawi, hak memperoleh kesejahteraan dan pekerjaan yang layak, termasuk yang bermuatan penegakan hukum. Jika penyelenggara kekuasaan mengimplementasikan tugas yang digariskan oleh hukum ini berarti menyelenggarakan tujuan ideal yang sudah melekat dalam diri negara hukum seperti menjaga dan melindungi kehidupan manusia harapan hukum telah terpenuhi ${ }^{4}$.

Konstitusi memiliki kedudukan penting dalam penyelenggaraan negara hukum. Menurut Aristoteles, konstitusi merupakan penyusunan jabatan dalam suatu negara dan menentukan apa yang dimaksud dengan badan pemerintahan dan akhir dari setiap masyarakat. Konstitusi merupakan aturan-aturan dan penguasa negara harus mengatur menurut aturan-aturan tersebut ${ }^{5}$. Pendapat Aristoteles tersebut pada intinya konstitusi adalah dasar hukum dari segala hukum daripada penguasa. Sehingga konstitusi menjadi pondasi dasar suatu negara.

Salah satu persoalan yang dialami oleh bangsa Indonesia adalah masih banyaknya sengketa di bidang pertanahan. Sengketa tanah yang terjadi disebabkan salah satunya adalah permasalahan regulasi. Bila dicermati permasalahan regulasi dibidang pertanahan

3 Soerjono Soekanto, Sosiologi Hukum Dalam Masyarakat, (Jakarta: Rajawali, 1979), hlm. 43.

4 Roscoe Pond, An Introduction to the Philosophy of Law, terjemahan, (Jakarta: Bhatara Niaga Media, 1996), hlm. 56.

5 Azhary, Negara Hukum Indonesia Analisis Yuridis Normatif Tentang Unsur-unsurnya, (Jakarta: Universitas Indonesia Press, 1995), hlm. 21. 
disebabkan perubahan politik hukum pertanahan yang sering kali berubah-ubah mengikuti keinginan rezim pemerintah saat itu.

Politik pertanahan Indonesia masih belum stabil dan seringkali berubah-ubah menurut keinginan dan kepentingan penguasa. Politik pertanahan sepatutnya lebih responsif dalam menjawab problematika regulasi pertanahan. Hukum yang responsif juga berarti nilainilai fundamental bangsa Indonesia yang terkandung dalam Pancasila dan UUD NRI Tahun 1945 harus menjadi jiwa dari kebijakan pertanahan ${ }^{6}$.

Undang-undang Nomor 5 Tahun 1960 atau yang sering disebut UUPA merupakan salah satu produk hukum yang lahir di zaman pemerintahan Orde Lama yang bertujuan untuk mengubah dan memperbaharui regulasi/peraturan perundang-undangan di bidang hukum agraria dan pertanahan demi terwujudnya pembangunan yang berdasarkan Pancasila dan UUD 1945. Kebijakan pemerintahan zaman Orde Lama lebih ditujukan untuk mewujudkan kemakmuran dan kesejahteraan rakyat sebagaimana amanat yang telah dinyatakan dalam Pasal 33 ayat (3) UUD NRI Tahun1945.

Di era pemerintahan Orde Baru kebijakan hukum pertanahan berorientasi pada kebijakan mikro ekonomi untuk mendukung pembangunan.Hal ini bisa diperhatikan banyak proyek mercusuar yang mengeksplorasi dan mengeksploitasi sumber daya alam secara besar-besaran. Sampai saat ini dampaknya masih dirasakan salah satunya keberadaan PT. Freeport Indonesia yang merupakan perusahaan tambang milik Amerika Serikat yang telah lama mengambil kekayaan asli alam Indonesia. Kebijakan pemerintahan Orde Baru dirasakan banyak merugikan bangsa Indonesia sehingga gelombang protes sering terjadi.Akan tetapi hal tersebut bisa diredam dan dibungkam dengan cara-cara diktator. Masyarakat kecil banyak yang terpinggirkan terutama petani dan buruh. Pada era Orde Baru banyak kasus-kasus pelanggaran hak asasi manusia (HAM) yang sampai saat ini masih belum terselesaikan sepenuhnya.

UUPA yang mengatur mengenai hukum agraria semestinya menjadi peraturan perundang-undangan payung (umbrella act). Akan tetapi dari beberapa peraturan perundang-undangan yang terkait dengan agraria tidak menjadi dasar yuridis dari sejumlah peraturan perundang-undangan. Hal ini menimbulkan disharmoni antara UUPA dengan sejumlah peraturan perundangundangan sektoral.

Penulis mencatat beberapa permasalahan regulasi pertanahan yang terkait dengan undang-undang sektoral lainnya seperti Undang-undang Nomor 7 Tahun 2004 tentang Sumber Daya Air. Keberadaan peraturan perundang-undangan tersebut ternyata tidak menjadikan UUPA sebagai dasar yuridisnya serta memiliki persoalan antara lain ditataran pemberian Hak Guna Air (HGA), Hak Guna

6 Bernhard Limbong, Konflik Pertanahan, (Jakarta: MP Pustaka Margaretha, 2012), hlm. 159. 
Usaha Air (HGUA) dan Hak Guna Pakai Air (HGPA). Istilah hak tersebut kurang tepat karena senyatanya bentuk riilnya adalah pemberian ijin. Hal tersebut menunjukkan perbedaan dengan Pasal 47 UUPA. Apalagi kemudian UUSDA telah dibatalkan oleh Mahkamah Konstitusi dengan Putusan Nomor 85/PUU-XI/2013 sehingga memberlakukan kembali UU Nomor 11 Tahun 1974. Hal ini menimbulkan persoalan regulasi pada implementasinya sampai saat ini.

Selanjutnya munculnya persoalan dengan UU Nomor 4 Tahun 2009 tentang Pertambangan Mineral dan Batubara (UU Minerba). Inkonsistensi muncul karena tidak menjadikan UUPA sebagai sumber hukum.Orientasi UU Minerba lebih condong kepada produksi bukan konservasi. Hal ini menguntungkan pihak swasta dan pengelola dan dapat merugikan negara. Polemik UU Minerba antara rezim pemerintah juga menguat karena perbedaan kepentingan rezim. Sejak keberadaan UU Minerba pemerintah dinilai kalah dengan kepentingan perusahaan karena banyak perusahaan yang tidak memenuhi kewajibannya serta cenderung mengabaikan kewajibannya kepada pemerintah. UU Nomor 4 Tahun 2009 juga tidak tegas mengatur mengenai ganti rugi bagi pemegang hak atas tanah yang tanahnya diambil untuk kepentingan kegiatan pertambangan.

Permasalahan regulasi juga terjadi dengan Undang-undang Nomor 41 Tahun 1999 tentang Kehutanan (UUK). UUPA mengakui keberadaan keberadaan tanah negara, tanah ulayat masyarakat adat dan tanah hak. Sedangkan UUK hanya mengakui keberadaan hutan negara dan hutan hak. Hal ini seringkali menimbulkan permasalahan implementasi dilapangan karena pemberian hak yang salah akibat tidak ada koordinasi antara BPN dengan Kementerian Kehutanan. UUK sama sekali tidak mengakui keberadaan hutan adat, padahal hutan adat merupakan bagian dari hak ulayat yang sampai saat ini masih dilindungi oleh negara sebagaimana amanat UUPA. UUK memasukkan UUPA sebagai dasar yuridis akan tetapi pada batang tubuhnya tidak mengacu kepada pasal-pasal di dalam UUPA sehingga menimbulkan disharmoni peraturan perundang-undangan tersebut.

Adapun analisis penulis penyebab terjadinya disharmoni peraturan perundangundangan antara lain:

1. Adanya pergantian rezim pemerintahan sehingga penyusunan peraturan perundang-undangan lebih sering berubah dan tidak berkelanjutan.

2. Belum ada standar baku, cara dan metodologi penyusunan peraturan perundang-undangan. Masingmasing instansi memiliki keinginan dan egosentris lebih mengutamakan kepentingan instansinya.

3. Pembentuk peraturan perundangundangan yang kurang menguasai permasalahan akibat seringkali terjadi pergantian antara pejabat.

4. Masih kurangnya akses masyarakat untuk turut serta dalam penyusunan rancangan 
peraturan perundang-undangan.

5. Kurangnya koordinasi antara instansi terkait.

Akibat hukum terjadinya dishamoni antara lain:

1. Munculnya ketidakpastian hukum,

2. Pelaksanaan peraturan perundangundangan menjadi tidak efektif dan efisien,

3. Terjadinya perbedaan interpretasi terhadap suatu peraturan perundangundangan

4. Hukum sebagai pedoman masyarakat dan pemerintah menjadi tidak berfungsi sebagaimana mestinya.

Penulis mencermati bahwa keberadaan UUPA juga dirasakan masih memiliki kekurangan antara lain:

1. Masih kaburnya kompetensi lembaga yang ditunjuk sebagai koordinator untuk menata, mengelola, mensinkronisasikan beberapa kebijakan agraria. Hal ini penting karena fakta dilapangan sering terjadi benturan kepentingan antar institusi.

2. Sudah tidak sesuai dengan perkembangan zaman. Hal ini seiring era globalisasi dimana diperlukan pengaturan yang bisa merespon kepentingan investasi tanpa mengorbankan kepentingan masyarakat.

3. Perlindungan hak masyarakat hukum adat, buruh dan petani masih kurang. Hal ini bisa dilihat masih maraknya konflikkonflik agraria yang masih sering terjadi. Peraturan perundang-undangan yang terkait di bidang agraria dan pertanahan seyogyanya perlu untuk disempurnakan dan diharmonisasikan dengan UUPA. Selain itu perlu dilakukan perbaikan kinerja serta penguatan kelembagaan instansi pertanahan dalam hal ini Kementerian Agraria dan Tata Ruang/ Badan Pertanahan Nasional Republik Indonesia.

Pemerintah pernah berupaya untuk merevisi UUPA sebagaimana diamanatkan dalam Ketetapan MPR RI No. IX/MPR/2001 tentang Pembaharuan Agraria dan Pengelolaan Sumber Daya Alam dan Keputusan Presiden No. 34 Tahun 2003 tentang Kebijakan Nasional di Bidang Pertanahan. Walaupun telah ada norma-norma tersebut, namun pembaharuan hukum di bidang agraria masih belum bisa diwujudkan. Rancangan UU Pertanahan yang pernah dibahas di legislatif faktanya sampai saat ini belum ada progres dan hasilnya. Padahal keberadaan UU Pertanahan sudah mendesak diperlukan. Pembaharuan hukum agraria harus tetap menempatkan Pancasila dan UUD NRI Tahun 1945 sebagai asas utama sebagaimana tujuan negara adalah mensejahterakan kehidupan bangsa Indonesia.

Persoalan regulasi dibidang pertanahan dapat disimpulkan antara lain:

1. Timbulnya sengketa kewenangan dalam pengelolaan sumber daya alam antara pemerintah pusat dengan pemerintah daerah pasca terbitnya peraturan perundang-undangan yang mengatur masalah otonomi daerah dan hubungan koordinasi antara departemen/instansi, 
akibat terbitnya peraturan perundangundangan yang sifatnya sektoral dimana keberadaannya saling bertentangan dan lebih condong mengutamakan kepentingan masing-masing departemen/ instansinya. Sehingga hal tersebut berpotensi menimbulkan konflik ego-sektoral dalam hal pengelolaan sumber daya alam;

2. Masih kurang mengakui kedudukan masyarakat adat atau penduduk asli yang telah hidup di wilayah setempat (Adat people) sebagai pemilik tanah adat pada era pembangunan saat ini. Banyak masyarakat adat yang menjadi korban pembebasan tanah untuk mewujudkan pembangunan;

3. Munculnya berbagai peraturan perundang-undangan yang sifatnya sektoral dimana secara norma tidak tunduk atau sesuai dengan asas-asas yang termuat dalam UUPA;

4. Sebagian besar tanah di Indonesia belum bersertifikat bahkan masih banyak kasus timbulnya sertifikat ganda pada bidang tanah yang diterbitkan oleh Kementerian Agraria dan Tata Ruang/ Badan Pertanahan Nasional Republik Indonesia? .

Sebagai suatu proses yang dinamis yang terus menerus mengalami perubahan sesuai dengan dinamika masyarakat, pembaharuan substansi hukum dan pembentukan peraturan perundang-undangan di bidang pertanahan perlu memperhatikan 3 (tiga) aspek antara lain:

Pertama, Sejarah bangsa Indonesia menjadi dasar pertimbangan dan pembelajaran. Pengalaman dan pertimbangan mengenai sejarah masa lalu tidak boleh dihilangkan dalam proses pembentukan peraturan perundang-undangan agar sejalan dengan tujuan dibentuknya negara Indonesia.

Kedua, kondisi obyektif yang terjadi di pemerintahan saat ini. Pemerintah perlu memperhatikan aspek-aspek hukum Pembentukan Peraturan Perundang-undangan yang baik agar peraturan perundang-undangan yang dirancang, dibentuk dan diterbitkan sesuai dengan peraturan perundang-undangan yang berlaku, baik lebih tinggi atau sederajat hirarkinya dan dapat sesuai dengan kebutuhan riil masyarakat, sehingga dapat diterapkan secara efektif dan efisien.

Ketiga, cita-cita yang hendak dicapai pada masa yang akan datang. Perspektif terhadap masa datang diperlukan agar lembaga legislatif dalam membentuk peraturan perundang-undangan mampu mengantispasi perkembangan masyarakat, budaya, ilmu pengetahuan, teknologi, informasi di era globalisasi yang tidak bisa dihindarkan.

Proses pembentukan peraturan perundangundangan yang baik akan mempengaruhi faktor-faktor penegakan hukum. Menurut Soerjono Soekanto, faktor-faktor penegakan

7 Lastuti Abubakar, "Revitalisasi Hukum Adat sebagai Sumber Hukum dalam Membangun sistem Hukum Indonesia", Jurnal Dinamika Hukum Vol. 13, No. 2, (Mei 2013): 323. 
hukum antara lain:

1. Faktor substansi hukum,

2. Faktor penegak hukum,

3. Faktor sarana prasarana dan fasilitas,

4. Faktor masyarakat,

5. Faktor kebudayaan ${ }^{8}$

Faktor-faktor penegakan hukum tersebut merupakan pengembangan dari pendapat Lawrence M. Friedman dengan teorinya Sistem Hukum (Legal System) yang terdiri: Substansi hukum (legal substance), Struktur hukum (legal structure), Budaya hukum (legal culture). Keunggulan teori Legal System dari Lawrence M. Friedman antara lain sebagai berikut:

1. Produk perundang-undangan dengan peraturan pelaksanaannya merupakan keinginan atau kemauan dari pimpinan. Hal ini sesuai dengan pernyataan L.M. Friedman sebagai berikut: A legal system cannot enforce or implement these rules and regulation wthout the work of a lot of men and women who carry out orders from above-policemen. Demikian juga di Indonesia hal ini sudah terjadi akibat dominannya partai, atau kuatnya Kolusi, Korupsi dan Nepotisme (KKN).

2. Legal Culture atau budaya hukum dari L.M. Friedman ini bisa dipakai sebagai pisau analisis untuk melihat suatu produk perundang-undangan. Produk perundang-undangan yang dimaksud apakah berpihak kepada Pemerintah, masyarakat dan swasta.
3. Kemudian juga suatu produk perundangundangan dapat dilihat mengarah kepada kepentingan atau kepada keperluan.

4. Selanjutnya teori Legal system dari L.M. Friedman ini sangat baik dalam hal menganalisis suatu masalah yang masih baru. Karena obyektifitasnya dapat memberikan hasil yang baik. Hal yang masih baru dalam tulisan ini adalah sekalipun kasus Internasional dan lain sebagainya. Hal mana para pelaku pembuat undang-undang, atau kasus pidana, perdata, Internasional para pembuat dan para pelaku atau para pemilik serta penjabat yang menangani hal tersebut masih ada.

Sedangkan kelemahan teori Sistem Hukum dari Lawrence M. Friedman ini dapat diuraikan sebagai berikut:

1. Legal culture yang ditentukan oleh L.M. Friedman seolah-olah hanya masyarakat yang menilai jalannya hukum. Dengan kata lain bagaimana persepsi masyarakat terhadap hukum. Dari hasil pengamatan bukan hanya masyarakat yang menilai jalannya hukum, bisa juga pemerintah, dalam hal ini pihak eksekutif, judikatif dan legislatif, serta pengusaha, lembaga Advokasi, Pers, Lembaga Swadaya Masyarakat(LSM), Lembaga mahasiswa, dan juga mahasiswa, serta Negara, organisasi internal dan eksternal lainnya.

2. L.M. Friedman, menyatakan yang

8 Soerjono Soekanto, Faktor-faktor Yang Mempengaruhi Penegakan Hukum, (Jakarta: RajaGrafindo Persada, 1983), hlm. 32. 
menghidupkan atau mematikan mesin itu adalah legal culture (budaya hukum), dan mesin itu adalah structure (aparat) sedangkan produksi perundang-undangan itu adalah subtstance (hasil mesin), serta legal system (sistem hukum) adalah Pabrik. L. M. Friedman menjelaskan hal itu sebagai berikut: Another way to visualize the three elements of law is to imagine legal "structure" as a kind of machine. "Substance" is what the machine manufactures or does. The "legal culture" is whatever or whoever decides to turn the machine on and off, and determines how it will be used. Dalam pengamatan penulis yang menghidupkan atau mematikan suatu produk perundang-undangan itu bukanlah semata-mata masyarakat, tetapi bisa juga pihak legislatif, judikatif, eksekutif, dan organisasi lainnya.

3. Dalam hal kaitannya produk perundangundangan, ternyata ada beberapa lagi yang bisa menghidupkan atau mematikan suatu kebijakan. Pada saat itu Friedman tidak memikirkan hal ini sesuai dengan perkembangan dan perubahan zaman.

4. Jadi teori L.M. Friedman mengenai Sistem Hukum, dalam struktur, bukan hanya meliputi, eksekutif, legislatif dan judikatif melainkan juga pihak badan hukum, Pemerintah, swasta, LSM serta masyarakat internal/eksternal, organisasi Internasional, Negara maupun sekutu dari beberapa Negara, dan lain-lainnya.
Hal ini dapat di lihat dari Legal Culture atau budaya hukum, yaitu bagaimana persepsi, pemerintah, swasta, lembaga dan masyarakat internal/eksternal terhadap hukum.Jadi tidak benar hanya masyarakat yang menilai hukum. Ternyata ikut juga semua unsur atau elemen dalam menentukan budaya hukum. Kemudian dalam substansi, yaitu peraturan daerah, ternyata di Negara berkembang ada juga aturan-aturan yang berbentuk kebiasaan, hukum adat.

5. Selanjutnya teori legal system dari L. M. Friedman ini kurang baik dalam hal menganalisis suatu masalah yang lama. Karena obyektifitasnya dapat memberikan hasil yang buruk. Hal yang lama dalam tulisan ini adalah suatu produk perundang-undangan atau kasus pidana, perdata dan sekalipun kasus internasional dan lain sebagainya. Hal mana para pelaku pembuat undang-undang, dalam kasus pidana, perdata, tata usaha negara, internasional, para pembuat dan pelaku atau para pemilik serta penjabat yang menangani hal tersebut sudah tidak ada lagi. Oleh karenanya untuk mencari data, informasi dan fakta kejadian pada waktu itu sukar diperoleh atau akurasi datanya kurang obyektif, yang barangkali hanya dapat dianalisis melalui pendekatan sejarah. Karena sejarah adalah masa lampau, maka kebenarannya sangat sulit dibuktikan.

Kembali kepada ketiga komponen sistem 
hukum itu harus saling menunjang satu sama lain secara integratif agar hukum tersebut berlaku efektif. Umpamanya suatu substansi hukum (norma hukum) tidak dapat ditegakkan tanpa adanya dukungan dari struktur hukum dan budaya hukum yang menggerakkannya,

Begitu juga sebaliknya, hukum pada hakekatnya merupakan abstraksi dan ketetapan/penegasan norma-norma dalam masyarakat, gambaran normatif ini secara sosiologis dirumuskan dalam pengertian penegakan hukum sebagai suatu proses untuk mewujudkan keinginan hukum menjadi kenyataan.

Sebagai sebuah negara hukum (rechsstaat) prinsip the rules of law harus ditegakkan dalam Negara Republik Indonesia. Bagi kita prinsip the rules of law itu tidak lain dari pada the rules of justice, penegakan hukum yang berintikan keadilan. Prinsip demikian perlu ditegaskan, karena diskriminasi penerapan hukum dalam realitasnya terlampau mencolok. Produk hukum dan penegakannya lebih berpihak kepada the rulling class, kelompok masyarakat yang mempunyai kekuasaan ekonomi atau kekuasaan politik pada pihak lain. Hak-hak masyarakat pencari keadilan yang sebagian besar berasal dari kelompok-kelompok powerlesness selalu dikesampingkan, substantive atau sociological justice selalu dinikmati oleh mereka yang powerfull sedang powerless hanya mendapatkan formil justice. Keadaan demikian dalam negara yang baru merdeka masih dapat dipahami karena menyangkut ketersediaan sumber daya manusia ${ }^{9}$.

Salah satu untuk menata peraturan perundang-undanganyaitumelaluiharmonisasi hukum.Pengembangan harmonisasi hukum sudah muncul di Jerman tahun 1902. Rudolf Stammler mengemukakan suatu konsep fungsi hukum adalah harmonisasi berbagai maksud, tujuan dan kepentingan antara individu dengan individu dan antara individu dengan masyarakat. Kemudian dalam praktik hukum di Roma tahun 1926, International Institute for the Unification of Private Law (UNIDROIT) Badan Internasional yang didirikan menurut perjanjian multilateral yang difasilitasi oleh Persatuan Bangsa Bangsa (United Nations) telah menciptakan cara untuk mengharmonisasikan dan mengkoordinasikan ketentuan-ketentuan Hukum Perdata dari negara-negara anggotanya.

Pada Tahun 1951 di Paris terbentuk Verdrag van Parijs tot Oprichting van Europese Gemeenschap voor Kolen en Staal (masyarakat Batubara dan Baja Eropa) melalui Perjanjian Paris 1951. Kemudian diikuti dengan Perjanjian Roma 1957 terbentuk European Gemeenschap van Atoomenergie (Masyarakat Energi dan Atom Eropa) dan European Economic Community (Masyarakat Ekonomi Eropa). Secara bersama merupakan kesatuan European Community dalam usaha

9 Satjipto Rahardjo, Masalah Penegakan Hukum, (Bandung: Sinar Baru, 1983), hlm. 109. 
integrasi ekonomi yang diwujudkan terutama melalui harmonisasi hukum di antara negaranegara anggota.

Harmonisasi hukum juga berkembang dalam ilmu hukum di Belanda sejak tahun 1970.Pemerintah Belanda membentuk Inter Departmental Commision for Harmonization of Legislation dan membentuk Ministry of Justice a Staff Bureau for Harmonization. Sehubungan dengan tujuan harmonisasi hukum tersebut, dikeluarkan petunjuk kepada semua lembaga pemerintahan di Belanda untuk melakukan harmonization of legislation.

Harmonisasi hukum merupakan salah satu instrumen hukum untuk menyesuaikan peraturan perundang-undangan, kebijakan pemerintah, putusan hakim, asas-asas hukum untuk meningkatkan kepastian hukum, keadilan, kesebandingan tanpa mengorbankan pluralisme hukum.Harmonisasi hukum ini dilakukan dengan pendekatan sistem (system approach). Pendekatan sistem yang digunakan dalam studi hukum ini adalah konotasi sistem sebagai wujud atau entitas (system as an entity).

Sistem hukum nasional dimaksud merupakan satu kesatuan hukum yang saling berkaitan satu sama lainnya dengan bersumber pada Pancasila dan UUD NRI Tahun 1945. Pancasila sebagai ideologi bangsa adalah suatu hal yang tidak bisa ditawar-tawar.Nilainilai Pancasila merupakan panduan hidup (way of life) bangsa Indonesia.
Sistem hukum nasional mencakup beberapa hal dimulai dari perencanaan hukum (legislation planning), pembentukan hukum (legislation process) dan dampak hukum (legal impact) yang merupakan bagian dari budaya hukum (legal culture). Dengan menyerap nilai-nilai yang ada dalam masyarakat maka sistem hukum nasional akan memberikan rasa keadilan (sence of justice) bagi masyarakat.

Untuk mewujudkan harmonisasi peraturan perundang-undangan sebagaimana diuraikan diatas ada beberapa langkah-langkah antara lain $^{10}$ :

1. Perlunya melakukan identifikasi dan analisis masalah dishamoni hukum serta mencari penyebab/akar masalahnya;

2. Melakukan upaya penemuan hukum melalui metode hukum melalui interpretasi hukum untuk membangun konstruksi hukum;

3. Melakukan penalaran hukum terhadap hasil interpretasi dan konstruksi hukum yang telah dibangun agar memenuhi unsur logika;

4. Menyusun argumentasi hukum yang rasional, terstruktur, terukur dan jelas diiringi dengan pemahamam sistem hukum yang baik sehingga tidak menimbulkan permasalahan hukum yang baru.

Sistem hukum nasional yang dijiwai Pancasila dan bersumber pada hukum positif tertinggi, yaitu UUD NRI Tahun 1945 sebagai

10 Kusnu Goesniadhie, Harmonisasi Sistem Hukum: Mewujudkan Tata Pemerintahan Yang Baik, (Malang: Nasa Media, 2010), hlm. 11. 
supreme law of the land, yang mampu menjamin kepastian, ketertiban, penegakan dan perlindungan hukum yang berintikan keadilan dan kebenaran. Untuk memahami hukum nasional, perlu dikemukakan terlebih dahulu pengertian sistem itu sendiri, karena hukum nasional sebagai suatu sistem akan mengikuti pada batasan-batasan dan ciriciri sistem. Istilah sistem telah banyak dirumuskan oleh para pakar, sehingga bunyi batasannya berbeda satu dengan lainnya yang penekanannya sesuai dengan konteks pembahasannya.

Dalam Black Law Dictionary, dinyatakan:

A system is orderly combination as of particulars, parts or elements into a whole; especially such combination according to some rational principle.

Menurut Bellefroid, "rechts systeem is een aan eensluitend geheel van rechtsregels, die naar beginselen georden zijn". Dikatakan oleh Bertalanffy, "systems are complexes of elements in interaction, to which certain law can be applied". Menurut Bertalanffy, sistem adalah himpunan unsur-unsur yang saling mempengaruhi, untuk mana hukum tertentu menjadi berlaku.

Hukum positif tersusun dalam suatu tatanan, mulai dari hukum dasar sampai pada hukum yang paling konkret dan individual, harus bersumber pada tata nilai dasar yang mengandung penilaian-penilaian etis. Nilainilai tersebut terdapat pada norma dasar yang menjadi pengikat susunan norma-norma positif sebagai satu kesatuan. Menurut Kelsen,
An 'order' is a system of rules. Law is not, as it is sometimes said, a rule. It is a set of rules having the kind of unity we understand by a system.

Hukum adalah seperangkat peraturan perundang-undangan yang mengandung semacam kesatuan atau daya pengikat yang dipahami sebagai suatu sistem. UUD NRI Tahun 1945 dan segala peraturan perundangundangan penjabaran dan pelaksanaannya, juga memiliki kesatuan atau daya pengikat bangsa Indonesia sebagai suatu sistem dalam negara.

Sistem merupakan tatanan yang teratur dari bagian-bagian yang berkaitan satu sama lain yang kemudian membentuk suatu pola tertentu. Dalam suatu sistem yang baik tidak boleh terjadi tumpang tindih antara bagianbagian tersebut. Sistem memiliki unsur-unsur yang bersumber dari nilai dan asas tertentu. Begitu pula sistem hukum yang merupakan tatanan teratur dari norma-norma yang berkaitan satu sama lainnya sehingga dapat berfungsi dengan baik dan mencapai tujuan yang hendak dicapai.

Menurut Lon L. Fuller dalam "Morality of Law" sebagaimana dikutip dalam buku Kusnu Goesniadhie"11, menerangkan, “A total failure in any one of these eight directions does not simply result in a bad system of law, it results in something that is not properly called a legal system at all” yang diartikan "Kegagalan total 
salah satu dari delapan tujuan ini tidak hanya menghasilkan sistem hukum yang buruk, namun juga menghasilkan sesuatu yang sama sekali tidak disebut sistem hukum sama sekali”.

$\begin{array}{rrrr}\text { Pernyataan } & \text { Lon } & \text { L.Fuller } & \text { tersebut } \\ \text { menerangkan } & \text { bahwa } & \text { sistem } & \text { hukum }\end{array}$
mengandung integritas moral tertentu. Hal tersebut diatur dalam prinsip-prinsip hukum (Principles of Legality) antara lain:

1. Hukum harus berlaku untuk semua tanpa pengecualian dan sifatnya permanen. Hal ini disebut asas kesetaraan dihadapan hukum (Equality before the Law).

2. Hukum harus diumumkan dan dipahami oleh semua pihak. Keberadaan hukum bukanlah suatu rahasia. Sehingga semua orang tahu mana yang boleh dilakukan dan mana yang dilarang.

3. Hukum tidak boleh berlaku surut (asas non retroaktif). Bilamana hukum berlaku surut maka akan memberikan rasa tidak nyaman dan ketidakpastian hukum. Hal ini selaras dengan asas legalitas.

4. Hukum harus jelas, tidak ambigu dan multitafsir. Hukum yang kabur akan menciptakan kekhawatiran bagi pihakpihak tertentu dalam melaksanakan suatu kebijakan. Hal ini akan menghambat jalannya hukum.

5. Hukum tidak boleh ada pertentangan antara satu sama lainnya. Hukum harus selaras satu sama lain yang kemudian menciptakan sistem hukum yang baik.

6. Hukum tidak boleh berlebihan dan melebihi kemampuan serta kapasitas pihak tertentu. Dengan demikian hukum tidak menjadi beban bagi pihak tertentu.

7. Hukum harus statis, tidak mudah berubahubah dan berlaku untuk jangka panjang. Proses pembentukan hukum sudah harus bisa menjangkau kebutuhan hukum yang berlaku dan masa akan datang.

8. Hukum harus bisa diterapkan dan dilaksanakan masyarakat. Dengan demikian masyarakat menerima hukum dengan sukarela tanpa ada rasa paksaan dari penguasa.

Dalam proses pembentukan suatu peraturan perundang-undangan maka kesadaran bahwa hukum itu adalah suatu sistem dapat diwujudkan dengan melakukan harmonisasi dan sinkronisasi terlebih dahulu. Istilah harmonisasi lebih menekankan pada keberadaan indikator-indikator dan karateristik yang sama dalam suatu peraturan, sedang sinkronisasi lebih mementingkan unsur penyelarasan bahwa suatu peraturan tidak boleh bertentangan dengan peraturan yang lain.

Dasar kebijakan pembentukan sistem hukum dan penegakkannya bergantung pada politik hukum yang stabil, tetap dan berkelanjutan sebagaimana dikemukakan Bagir Manan antara lain ${ }^{12}$ :

1. Satu kesatuan sistem hukum nasional;

2. Sistem Hukum Nasional yang dibangun 
harus berdasarkan Pancasila dan UUD NRI Tahun 1945;

3. Tidak ada diskriminasi hukum yang memberikan hak istimewa kepada individu, kelompok, suku, ras dan agama;

4. Pembentukan hukum harus memperhatikan kemajemukan bangsa Indonesia;

5. Hukum adat dan hukum kebiasaan diakui sebagai bagian sistem hukum nasional sepanjang masih ada dan tetap dipertahankan dalam masyarakat;

6. Pembentukan hukum harus didasarkan pada partisipasi masyarakat;

7. Hukum yang dibentuk dan ditegakkan harus membawa kesejahteraan umum dan keadilan sosial bagi seluruh rakyat Indonesia sehingga terwujud masyarakat yang demokratis dan mandiri.

Politik hukum yang stabil tersebut harus dipresentasikan melalui wakil-wakil rakyat dalam membentuk peraturan perundangundangan (regulasi).

Akan tetapi permasalahan regulasi di Indonesia tidak hanya bisa diselesaikan melalui harmonisasi melainkan butuh terobosan hukum salah satunya melalui konsep Omnibus Law. Konsep Omnibus Law yang diterapkan di beberapa negara seperti Amerika Serikat, Belgia, Inggris menawarkan pembenahan permasalahan timbulnya konflik dan tumpang tindih (overlapping) suatu norma/ peraturan perundang-undangan. Bila hendak dibenahi satu persatu maka akan memakan waktu yang cukup lama dan biaya yang tidak sedikit. Belum lagi proses perancangan dan pembentukan peraturan perundang-undangan di pihak legislatif seringkali menimbulkan deadlock atau tidak sesuai kepentingan.

Hal ini pada akhirnya menghabiskan energi, waktu, biaya dan tujuan yang hendak dicapai tidak tepat sasaran. Ditambah lagi turunnya tingkat kepercayaan publik terhadap kinerja legislatif. Untuk itu diperlukan terobosan hukum dari pemerintah untuk menyelesaikan permasalahan regulasi.

Untuk mencapainya maka perlu dilandasi regulasi yang kuat. Salah satu negara yang mengadopsi Omnibus Law adalah Serbia. Omnibus Law adalah hukum yang diadopsi pada Tahun 2002 yang mengatur status otonom Provinsi Vojvodina yang termasuk di dalam Serbia. Hukum tersebut mencakup yuridiksi pemerintah Provinsi Vojvodina mengenai budaya, pendidikan, bahasa, media, kesehatan, sanitasi, jaminan kesehatan, pensiun, perlindungan sosial, pariwisata, pertambangan, pertanian, dan olahraga.

Omnibus Law termasuk hal yang baru di Indonesia walaupun negara-negara lain telah menerapkan seperti Amerika Serikat (The Omnibus Actof June 1868, The Omnibus Actof February 22,1889), Kanada (Criminal Law Amandment Act, 1968-69), Philipine (Tobacco Regulation Act of 2003) dan 39 negara yang mengadopsi Omnibus Law dalam hal perlindungan data personal yang dirilis

13 Privacy Exchange.org, "A global information resource on consumers,commerce, and data protection worldwide National Omnibus Laws”, http://www.privacyexchange.org/legal/nat/omni/nol.html, diakses 13 April 2017. 
Privacy Exchange.org (A global information resource on consumers,commerce, and data protection worldwide National Omnibus Laws) $)^{13}$, seperti Argentina, Australia, Austria, Belgium, Canada, Chile, Czech Republic, Denmark, Estonia, Finland, France, Germany, Greece, Hungary, Iceland, Ireland, Israel, Italy, Japan, Latvia, Liechtenstein, Lithuania, Luxembourg, Malta, The Netherlands, New Zealand, Norway, Poland, Portugal, Romania, Russia, Slovak Republic, Slovenia, Spain, Sweden, Switzerland, Taiwan, Thailand, dan United Kingdom.

Definisi daripada Omnibus Law dimulai dari kata Omnibus. Kata Omnibus berasal dari bahasa Latin dan berarti untuk semuanya. Di dalam Black Law Dictionary Ninth Edition Bryan A.Garner disebutkan omnibus : relating to or dealing with numerous object or item at once ; inculding many thing or having varius purposes, dimana artinya berkaitan dengan atau berurusan dengan berbagai objek atau item sekaligus; termasuk banyak hal atau memiliki berbagai tujuan. Bila digandeng dengan kata Law yang maka dapat didefinisikan sebagai hukum untuk semua.

Di dalam hierarki / tata urutan peraturan perundang-undangan di Indonesia sebagaimana diatur di dalam Undang-undang Nomor 12 Tahun 2011 tentang Pembentukan Peraturan Perundang-undangan, belum memasukkan konsep Omnibus Law sebagai salah satu asas dalam sumber hukum. Tetapi harmonisasi peraturan perundang-undangan di Indonesia terus menerus dilakukan untuk meminimalkan konflik peraturan perundang- undangan. Sistem hukum Indonesia yang menganut sistem Civil Law menjadi salah satu penyebab belum dikenalnya konsep Omnibus Law.

Dari permasalahan harmonisasi peraturan perundang-undangan di Indonesia, maka pemerintah perlu mengambil suatu upaya terobosan hukum untuk membenahi konflik regulasi. Tuntutan perbaikan dan pembenahan tumpang tindih peraturan perundangundangan di Indonesia sudah sangat mendesak untuk dilakukan. Salah satu gagasan Omnibus Lawberkemungkinan untuk diterapkan di Indonesia asalkan diberikan ruang dan fondasi hukum.

Omnibus Law bukanlah hal baru di dunia ilmu hukum secara global, hanya saja untuk di Indonesia sudah sangat diperlukan untuk membenahi tumpang tindih peraturan perundang-undangan. Proses harmonisasi peraturan perundang-undangan selain hambatan diatas juga memakan waktu yang lama. Dengan konsep Omnibus Law maka peraturan yang dianggap tidak relevan atau bermasalah dapat diselesaikan secara cepat.

Akan tetapi beberapa kalangan akademisi juga ada yang menilai bila konsep Omnibus Law diberlakukan maka bertentangan dengan asas demokrasi, karena konsep Omnibus Law sebagian kalangan menilainya anti demokratis. Akan tetapi pertanyaan terbesar, apakah kita harus terus membiarkan konflik peraturan perundang-undangan?. Pemerintah perlu melakukan terobosan hukum agar mampu menyelesaikan permasalahan tumpang tindih 
beberapa peraturan perundang-undangan tersebut.

Tata urutan peraturan perundangundangan di Indonesia sudah harus direvisi dan memberikan ruang untuk menerapkan konsep Omnibus Law. Apalagi kondisi saat ini pengambil kebijakan dapat dengan mudah dikriminalisasikan oleh aparat penegak hukum. Pemahaman ilmu hukum aparat penegak hukum mayoritas memakai kacamata positivisme hukum, sehingga sulit memberikan ruang pengambil kebijakan dalam hal ini pejabat untuk melakukan diskresi. Seringkali diskresi yang dilakukan oleh pejabat pengambil kebijakan berujung pidana karena didakwa melakukan tindak pidana korupsi.

Hal tersebut merupakan sebuah ironi dimana Indonesia sebagai negara hukum dengan segala perangkatnya bertujuan untuk melindungi hak asasi manusia dan memberikan keadilan bagi sebagian besar warganya yang sangat mendesak sekarang "membawa keadilan kepada rakyat" (to bring justice to the people) dengan menyelesaikan secara baik persoalan-persoalan yang oleh rakyat dianggap harus diselesaikan secara hukum. Persoalan lain bilamana perbuatan itu tidak disukai atau dibenci oleh masyarakat karena merugikan atau menimbulkan korban. Dengan kata lain, sejauh mana persoalan atau perbuatan tersebut bertentangan dengan nilainilai yang berlaku dalam masyarakat dan masyarakat menganggap patut atau tidak patut dihukum dalam rangka menyelenggarakan kesejahteraan dan keamanan masyarakat.

Tujuan hukum abstrak di tengah-tengah suatu masyarakat yang kompleks ini hanya dapat diwujudkan melalui pengorganisasian yang kompleks pula. Hal ini dimaksud bahwa masyarakat akan menerima tujuan hukum tersebut. Tujuan hukum antara lain menciptakan ketentraman dan menegakkan keadilan. Dengan demikian masyarakat tidak akan melakukan main hakim sendiri atau hukum jalanan (street justice). Masyarakat hukum akan sepenuhnya menyerahkan pada proses hukum karena mampu memberikan rasa kepastian hukum (rechtszekerheid).

Ketertiban dan keamanan menjadi sesuatu yang nyata melalui tindakan-tindakan pihak Kepolisian. Dapat dikemukakan bahwa penegakan hukum selalu akan melibatkan manusia di dalamnya dan dengan tingkah laku manusia itu sendiri. Hukum tidak bisa berjalan sendiri melainkan harus dilaksanakan oleh masyarakat. Peraturan-peraturan hukum dimaksud menjadi suatu kontrak sosial dan memberikan kepastian hukum di dalam masyarakat. Dengan demikian kesadaran hukum timbul dengan sendirinya seiring peningkatan kepercayaan terhadap aparatur penegak hukum. Hukum dimaksud bisa berupa hukum pidana, hukum perdata, hukum keluarga dan bidang-bidang hukum lain.

Terkait masalah penegakan hukum selalu akan melibatkan manusia dan tingkah lakunya.Tingkah laku manusia merupakan konsekuensi dari sejumlah pandangan, pengertian, batasan-batasan atau kompleksitas 
makna yang mereka miliki, karena demikian halnya maka setiap realitas selalu bersifat objektive interpretative dan itulah fenomena yang tampak kalau mau menghayati. Untuk menjelaskan tingkah laku manusia melalui analisis makna ini, maka dikemukakan disini teori dari aliran Interaksionis Simbolik yang antara lain dipelopori oleh Charles Horton dan W.I Thomas. ${ }^{14}$.

Teori Interaksionis Simbolik ini dalam menjelaskan tingkah laku manusia menyandarkan kepada tiga premis, yaitu:

Pertama, bahwa manusia itu berbuat ke arah sesuatu atas dasar makna yang melekat pada sesuatu itu, Artinya, pada sesuatu itu ada makna, sesuatu itu sekedar simbol dari makna dan tindakan manusia ditujukan untuk mengejar makna itu

Kedua, bahwa makna tentang sesuatu berkembang dari atau melalui interaksi antar manusia dalam kehidupan sehari-hari, ini sejalan dengan arus perkembangan budaya itu sendiri, sebagai suatu hasil saling membagi makna ("shared system of meanings") makna-makna dimaksud dipelajari, direvisi, dipelihara dan diberi batasan-batasan dalam konteks interaksi manusia.

Ketiga, makna-makna tersebut di pegang, dijadikan acuan dan interpretasikan oleh seseorang dalam berhubungan dengan sesuatu yang dihadapi, ia gunakan sebagai acuan untuk menafsirkan sesuatu situasi, keadaan, benda atau lainnya dalam kehidupan sehari- hari. ${ }^{15}$

Kemajemukan perilaku manusia turut memicu timbulnya konflik. Konflik pertanahan telah menjadi persoalan bangsa yang begitu kompleks saat ini dan mendesak untuk dicarikan jalan keluarnya. Menanggapi persoalan bangsa tersebut, upaya responsif harus menjadi prioritas untuk dijalankan oleh pengambil keputusan/pemerintah. Sekurang-kurangnya, ada beberapa hal mendasar yang harus dilakukan dalam rangka mencari solusi terhadap konflik pertanahan, yakni: membentuk komisi penyelesaian konflik pertanahan, reforma agraria sebagai suatu kebutuhan sekaligus reformasi regulasi pertanahan, melakukan penguatan kelembagaan Kementerian Agraria dan Tata Ruang/Badan Pertanahan Nasional Republik Indonesia, dan membentuk lembaga peradilan adhoc khusus menyelesaikan masalah pertanahan.

Keadilan agraria yang dicita-citakan sepertinya menjadi suatu utopia bagi masyarakat dinegeri ini yang sebagian besar mata pencahariannya di bidang agraris. Akses terhadap tanah belum sepenuhnya dirasakan oleh para petani. Bersamaan dengan itu, konflik pertanahan pun tak kunjung reda, terutama konflik yang dilatar belakangi oleh pemilikan dan pemanfaatan tanah atau yang dikenal dengan konflik struktural. Masyarakat berada dalam konflik berhadapan dengan struktural dalam masyarakat entah itu pemerintah atau badan hukum swasta. Kenyataan ini 
memberikan sebuah asertasi bahwa reformasi agraria mendesak untuk dilaksanakan. Keadilan agraria harus ditegakkan dan mewujud dalam pendistribusian tanah dan ketersediaan akses terhadap tanah bagi masyarakat.

Reformasi agraria harus dibuktikan dalam tindakan nyata, bukan sekedar retorika atau teori semata. Di dalam Tap MPR RI Nomor:IX/MPR/2001 mengamanatkan DPR RI bersama Presiden untuk segera mengatur lanjut pelaksanaan pembaharuan agraria dan pengelolaan sumber daya alam lebih lanjut serta mencabut, mengubah dan/atau mengganti semua peraturan perundangan-undangan terkait yang tidak sejalan dengan ketetapan ini. Mandat ini seyogyanya ditindak lanjuti secara konkret oleh Pemerintah dan DPR dengan meninjau kembali peraturan perundangan yang ada dan mensinkronkannya serta menyesuaikannya dengan prinsip dan arahan kebijakan yang dimandatkan dalam ketetapan ini. Pelaksanaan reforma agraria tentu akan menghasilkan politik hukum pertanahan yang mampu menjamin perlindungan hukum dan peningkatan kesejahteraan serta mendorong kegiatan ekonomi bagi masyarakat.

Kementerian Agraria dan Tata Ruang/ Badan Pertanahan Nasional Republik Indonesia sebagai lembaga yang diberikan kewenangan khusus untuk mengelola pertanahan nasional harus dibenahi secara kelembagaan dan organisasi mulai dari tingkat pusat hingga daerah. Kementerian Agraria dan Tata Ruang/BPN RI harus menjalankan prinsip 3G (good goverment governance) atau tata kelola pemerintahan yang baik dalam menjalankan wewenangnya. Layanan profesional, transparansi, akuntabilitas harus benar-benar diterapkan dan dijalankan mulai dari jajaran pimpinan sampai jajaran pelaksana tugas.

Selain ituKementerian Agraria dan Tata Ruang/Badan Pertanahan Nasional Republik Indonesia perlu untuk meningkatkan hubungaan koordinasi antar lembaga atau institusi pemerintahan terkait dalam menyelesaikan konflik misalnya konflik tanah perkebunan, pengambilan tanah hutan negara. Kementerian Agraria dan Tata Ruang/Badan Pertanahan Nasional Republik Indonesia telah diberikan kewenangan yang menyangkut semua atribusi yang berkaitan dengan pengelolaan, pemanfaatan, serta peruntukkan tanah. Oleh karena itu Kementerian Agraria dan Tata Ruang/Badan Pertanahan Nasional Republik Indonesia harus seintensif mungkin berkoordinasi dengan kementeriankementerian terkait dalam menyelesaikan konflik pertanahan.

Masalah pertanahan merupakan persoalan bangsa yang sifatnya kompleks terutama karena menyangkut hajat hidup orang banyak. Tanah merupakan sarana produksi dan turut menjamin kesejahteraan rakyat. Akibatnya, konflik pertanahan rawan terjadi terutama bila masyarakat tidak lagi memiliki akses terhadap tanah. Untuk membenahi semua persoalan pertanahan maka suatu keharusan untuk melakukan reformasi regulasi dibidang pertanahan. Omnibus Law yang nanti bisa 
diwujudkan dalam bentuk peraturan terpadu (Omnibus Regulation) akan meminimalisir benturan peraturan perundang-undangan yang terkait bidang tertentu, misalnya bidang pertanahan. Undang-undang pertanahan bisa menjadi peraturan perundang-undangan yang terpadu mengatur hal kebijakan hukum pertanahan.Persoalan pertanahan di Indonesia menjadi salah satu faktor penurun iklim investasi di Indonesia.

Persoalan pelik regulasi muncul dan menyebabkan iklim investasi di Indonesia bergerak lambat dibandingkan negara tetangga seperti Singapura dan Malaysia. Di Rezim Presiden Jokowi menghendaki semua regulasi yang menghambat masuknya dan berjalannya investasi harus dihapus. Menteri Agraria dan Tata Ruang/BPN RI Sofyan Jalil melontarkan gagasan konsep Omnibus Law untuk menyelesaikan sengketa tumpang tindih peraturan perundang-undangan yang menghambat pertumbuhan investasi di Indonesia.

Mencermati sistem perundang-undangan di Indonesia, Undang-Undang hasil konsep Omnibus Law bisa mengarah sebagai Undang-Undang Payung karena mengatur secara menyeluruh dan kemudian mempunyai kekuatan terhadap aturan yang lain. Akan tetapidi Indonesia justru tidak menganut Undang-Undang Payung karena posisi seluruh Undang-Undang adalah sama. Persoalan yang muncul bila dikaji dari perspektif teori peraturan perundang-undangan mengenai kedudukannya, sehingga kedudukannya harus diberikan legitimasi dalam Undang-undang Nomor 12 Tahun 2011 tentang Pembentukan Peraturan Perundang-undangan harus diamandemen.

Proses pembentukan peraturan perundangundangan dari kajian teoritis terkait dengan adanya dan berlaku hukum di dalam masyarakat dikenal sebagai Pengembanan Hukum (rechtsbeoefening). Kegiatan ini meliputi kegiatan dalam membentuk, melaksanakan, menerapkan, menemukan, menafsirkan, mempelajari dan mengajarkan hukum. Pengembanan hukum dibedakan dalam Pengembanan Hukum Praktis dan Pengembanan Hukum Teoretis ${ }^{16}$.

Pengembanan Hukum Praktis merupakan kegiatan manusia berkenaan dengan hal mewujudkan hukum dalam kenyataan kehidupan sehari-hari secara konkret. Kegiatan ini meliputi Pembentukan Hukum, Penemuan Hukum dan Bantuan Hukum.

Sedangkan Pengembanan Hukum Teoretis disebut juga sebagai Refleksi Teoretis tentang hukum, yaitu sebagai kegiatan akal budi untuk mendapatkan penguasaan intelektual tentang hukum atau pemahaman secara ilmiah atas hukum, yakni secara metodis sistematis logis rasional. Pengembanan Hukum Teoretis dibedakan dalam 3 (tiga) jenis berdasarkan tingkat abstraksinya atau berdasarkan tataran analisisnya (level of analysis), yaitu Ilmu-ilmu 
Hukum, Teori Hukum dan Filsafat Hukum.

Persoalan regulasi dibidang pertanahan refleksi tujuan kritis daripada pengembangan hukum itu sendiri. Hukum harus hidup diantara masyarakat dan dapat merekayasa masyarakat untuk tujuan yang baik. Keberadaan lembaga legislasi yang menjalankan fungsinya dengan baik. Proses pembentukan peraturan perundang-undangan adalah proses pembentukan peraturan perundang-undangan terdiri dari beberapa tahap legislasi dimulai dari perencanaan, persiapan, teknik penyusunan, perumusan, pembahasan, pengesahan, pengundangan dan penyebarluasan $^{17}$.

Proses pembentukan hukum yang baik tidak akan melahirkan permasalahan dikedepannya. Persoalan saat ini dalam proses pembentukan hukum banyak sekali kepentingan para pihak. Inilah yang menyebabkan produk perundang-undangan yang cacat sejak lahir. Untuk memperbaiki pun membutuhkan biaya, waktu, tenaga dan proses yang cukup rumit seperti halnya pengajuan judicial review ke Mahkamah Agung.

Pemerintah perlu mengambil langkah hukum dengan mengeluarkan paket kebijakan yang dapat membantu menyelesaikan sengketa regulasi di bidang pertanahan. Teknisnya Presiden bisa menerbitkan Peraturan Pemerintah Pengganti Undangundang (Perpu). Dengan Perpu tersebut diharapkan adanya percepatan penyelesaian regulasi dibidang pertanahan yang dapat menghambat iklim investasi. Lahirnya Perpu tersebut melalui koordinasi dengan beberapa kementerian terkait agar tidak menimbulkan permasalahan dikemudian harinya.

Ada beberapa kelebihan penerapan konsep Omnibus Law dalam menyelesaikan sengketa regulasi di Indonesia antara lain:

1. Mengatasi konflik peraturan perundangundangan secara cepat, efektif dan efisien.

2. Menyeragamkan kebijakan pemerintah baik di tingkat pusat maupun didaerah untuk menunjang iklim investasi;

3. Pengurusan perizinan lebih terpadu, efisien dan efektif;

4. Mampu memutus rantai birokrasi yang berlama-lama;

5. Meningkatnya hubungan koordinasi antar instansi terkait karena telah diatur dalam kebijakan omnibus regulation yang terpadu

6. Adanya jaminan kepastian hukum dan perlindungan hukum bagi pengambil kebijakan.

Penataan reformasi regulasi dengan menggunakan konsep Omnibus Law akan sulit untuk diterapkan dilapangan apabila tidak ada peran serta pemangku kepentingan dan koordinasi antar instansi terkait. Merujuk kepada konsep pelayanan satu atap harus menjadi model pelayanan dan pemberian izin sehingga para investor tidak direpotkan atau merasa dipermainkan oleh instansi terkait. Tentunya subtansi peraturan perundang- 
undangan yang baru harus dibuat seefisien mungkin. Perizinan yang sifatnya tidak perlu dan memanjang birokrasi harus dibabat habis.

Sedangkan kelemahan penerapan konsep ini bila diterapkan antara lain:

1. Membuka peluang akan ditolak pada saat paripurna atau di judial review terhadap kebijakan omnibus regulation yang diterbitkan;

2. Legislatifmerasa "dikebiri” karena proses pembentukan peraturan perundangundangan tidak melibatkan legislatif;

3. Akan mempengaruhi stabilitas sistem hukum nasional akibat orientasi kebijakan pemerintah yang berubah sesuai kehendak rezim yang memerintah.

Untuk meningkatkan pelayanan perizinan investasi perlu didukung dengan sarana prasarana hukum, salah satunya dengan memanfaatkan sistem teknologi informasi yang disiapkan sesuai kebutuhan. Sistem informasi teknologi tersebut dirangkai satu kesatuan dan terkoneksi antar instansi terkait. Dengan demikian kecepatan pelayanan perizinan investasi dapat maksimal.

\section{Simpulan}

Kebutuhan reformasi regulasi di bidang pertanahan sangat mendesak dilakukan karena dapat berimbas kepada turunnya iklim investasi di Indonesia. Terjadinya konflik agraria salah satunya disebabkan konflik regulasi. Untuk itu perlu dicarikan solusi atau terobosan untuk menata kembali politik pertanahan.
Reformasi regulasi pertanahan perlu dilakukan pemerintah dengan mengacu sistem hukum di Indonesia. Sistem Hukum Indonesia sangat menentukan arah kebijakan pemerintah. Bila sistem hukumnya baik maka arah kebijakan pemerintah akan tersistematis dan efektif.

Inilah saatnya pemerintah untuk merekonstruksi regulasi salah satunya regulasi pertanahan agar dapat meningkatkan iklim investasi di Indonesia. Akan tetapi reformasi regulasi tersebut jangan sampai mengorbankan kepentingan dan kesejahteraan rakyat Indonesia.

Gagasan konsep Omnibus Law diharapkan dapat menyelesaikan konflik regulasi di bidang pertanahan dan diharapkan efektif menyelesaikan konflik regulasi yang sudah lama mendera dan akibatnya bisa berujung kepada kriminalisasi pejabat. Untuk itu dalam menerapkan konsep ini, maka harus diberikan landasan hukum yang kuat sehingga tidak bertentangan dengan asas dan norma pembentukan peraturan perundang-undangan. Teknisnya bisa dengan menerbitkan Peraturan Pemerintah Pengganti Undang-undang (Perppu). Dengan Perppu tersebut diharapkan adanya percepatan penyelesaian regulasi dibidang pertanahan yang dapat menghambat iklim investasi. Beberapa kelebihan penerapan konsep Omnibus Law dalam menyelesaikan sengketa regulasi di Indonesia antara lain:

1. Mengatasi konflik peraturan perundangundangan secara cepat, efektif dan efisien. 
2. Menyeragamkan kebijakan pemerintah baik di tingkat pusat maupun didaerah untuk menunjang iklim investasi;

3. Pengurusan perizinan lebih terpadu, efisien dan efektif;

4. Mampu memutus rantai birokrasi menjadi sederhana;

5. Meningkatnya hubungan koordinasi antar instansi terkait karena telah diatur dalam kebijakan omnibus regulation yang terpadu

6. Adanya jaminan kepastian hukum dan perlindungan hukum bagi pengambil kebijakan.

Sedangkan kelemahan penerapan konsep ini bila diterapkan antara lain:

1. Membuka peluang akan ditolak pada saat

paripurna atau di judial review terhadap kebijakan omnibus regulation yang diterbitkan;

2. Legislatif merasa “dikebiri” karena proses pembentukan peraturan perundangundangan tidak melibatkan legislatif;

3. Akan mempengaruhi stabilitas sistem hukum nasional akibat orientasi kebijakan pemerintah yang berubah sesuai kehendak rezim yang memerintah.

Bentuk penyelesaian sengketa regulasi melalui penerapan gagasan Omnibus Law diharapkan agar iklim investasi Indonesia meningkat efektif dan efisien serta konflik agraria yang bersumber dari permasalahan regulasi dapat diselesaikan.

\section{DAFTAR PUSTAKA}

\section{Buku}

Azhary. Negara Hukum Indonesia Analisis Yuridis Normatif Tentang Unsurunsurnya. Jakarta: Universitas Indonesia Press, 1995.

Busroh, Firman Freaddy. Teknik Perundangundangan suatu Pengantar. Jakarta: Cintya Press, 2016.

Garner, Bryan A. Black Law Dictionary Ninth Edition. USA: A Thomson Reuters business, 2004.

Goesniadhie, Kusnu. Harmonisasi Sistem Hukum: Mewujudkan Tata Pemerintahan Yang Baik. Malang: Nasa Media, 2010.

Limbong, Bernhard. Konflik Pertanahan

Jakarta: MP Pustaka Margaretha, 2012.
Manan, Bagir. Beberapa Masalah Hukum Tata Negara Indonesia. Bandung: Alumni, 1997.

Pond, Roscoe. An Introduction to the Philosophy of Law. Terjemahan. Jakarta: Bhatara Niaga Media, 1996.

Rahardjo, Satjipto. Hukum, Masyarakat \& Pembangunan. Bandung: Alumni, 1981.

\section{Masalah Penegakan}

Hukum. Bandung: Sinar Baru, 1983.

Rasjidi, Lili dan Liza Sonia Rasjidi. Dasardasar Filsafat dan Teori Hukum. Bandung: Citra Aditya Bakti, 2016.

Sihombing, B.F. Evolusi Kebijakan Pertanahan Dalam Hukum Tanah Indonesia. Jakarta: Toko Gunung Agung Tbk, 2005. 


\section{Faktor-faktor yang Naskah Internet}

mempengaruhi penegakan hukum. Burhani, Ruslan. "BPN Sederhanakan Aturan Jakarta: Raja Grafindo Persada, 1983. Soekanto, Soerjono. Sosiologi Hukum

Dalam Masyarakat. Jakarta: Penerbit Rajawali, 1979.

\section{Jurnal}

Abubakar, Lastuti. "Revitalisasi Hukum Adat sebagai Sumber Hukum dalam Membangun sistem Hukum Indonesia”. Jurnal Dinamika Hukum Vol. 13, No. 2, (Mei 2013): 319-331.

Isra, Saldi. Fungsi Legislasi Setelah Perubahan UUD 1945. Jurnal Hukum Jentera Edisi 20 Tahun V, (JanuariApril 2010): 31-40. Pertanahan". http://www.antaranews. com/berita/376127/bpn-sederhanakanaturan-pertanahan. Diakses 12 April 2017.

FNH. "Menimbang Konsep Omnibus Law diterapkan di Indonesia”. http:// www.hukumonline.com/berita/baca/ 1t58a6fc84b8ec3/menimbang-konsepomnibus-law-bila-diterapkan-diindonesia. Diakses 13 April 2017.

Privacy Exchange.org. "A global information resource on consumers,commerce, and data protection worldwide National Omnibus Laws". http://www. privacyexchange.org/legal/nat/omni/ nol.html. Diakses 13 April 2017. 